\title{
J. FUKANO, M.D.: STUDIES ON THE PROTEUS ISOLATED FROM CHRONIC PURULENT OTITIS MEDIA
}

\section{慢性化膿性中耳炎から分離した変形菌に就て}

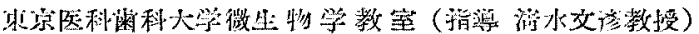

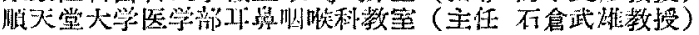

$$
\text { 染野 学郎 }
$$

\section{I. 緒論}

1885 年 Hauser ${ }^{12}$ が始めて萻敗菌として変形菌 を記载して以来变形菌による敗血症，食卟毒及び慢

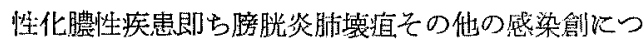
いて多くの研究及び報告がなされた。耳鼻科領域に 括いても慢性中耳炎の頭蓋内合併症の起炎菌として 静脈洞血栓，静脈洞周囲炎，脳膿揘，脳膜炎につい て古〈は Kanthack ${ }^{2)}$, Lang ${ }^{3)}$, Leutert ${ }^{4)}$, Lau(fs ${ }^{6)}$, 和田 ${ }^{6)}$ ，大西 ${ }^{7)}$ 等の報告にはじまつて現在に 至る沦多数の報告が見られる. 又その原因である慢

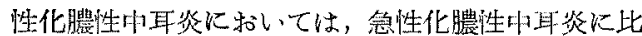
して屡々资形菌が検出されれるこは多くの交献に述

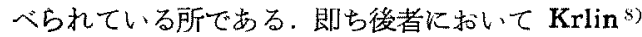
は 2000 例中 $0.6 \%$ K，Friedmann ${ }^{9)}$ は 664 例中 16 例に变形菌を検出し，その他の報告でも1\%内外の 検出率のるのが多いにか力わらず，慢性化澧性中耳 炎に却いては約 $30 \%$ 内外の検出率名 報告されてい る、特に最近進歩したサルフア削及び各種の抗生物 質の潦法が行われる際にも交形菌は執拗な抵抗性を 示す故に慢性小耳炎について他のブドゥ球菌及びュ リネバクテリウム, 緑膿菌, 真菌等と共に重要視さ れて来た。著者は慢性化膿性中耳炎より分耀した変 形菌 52 菌株について以下の実験を行つた。

\section{II. 実験材料及び分離培蓋}

検出の材料は慢性化膿性中耳炎患者の分趾物であ つて，患者の外耳道をビロゾンでもつて型の如く清 战消毒後可及的に鼓空内の分泌物を隇菌綿棒で採取 した。そのま〉普通寒天培地及び血液寒天培地に塗 琳 $37^{\circ} \mathrm{C} 24$ 時間培盖後特有な做受性の発育を示す ものを更に $0.2 \%$ の'石宸酸加普通寒天平板培地及び

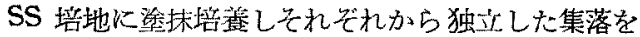
拾つて分離培荃し，更にウレアーゼ疾生の有無气の 他を検查して変形菌としての性状を確かめた。分 離後の 变形菌 52 菌株は $0.5 \%$ 半流動寒天培地に 第刺培養し $0^{\circ} \mathrm{C}$ の水室に保存し以下の実験化击し た。

検出の成績は表 1 の通り慢性化澧性中耳炎 202 例 より 52 菌株を離し，検出率は $25.7 \%$ であつた。 この中純培盖の形で出たものは 15 菌株で約 $29 \%$ を 占め，他の菌との混合感染の形を示したものは37 菌株で混在した菌は白色及び黄色ブドゥ球菌が大部 分であつた，検出率は夏季が最も高く $35 \%$ を示し その他の時季は大体 $15 \%$ 前後であつた。

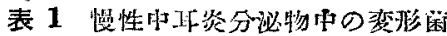

\begin{tabular}{|c|c|c|c|c|c|c|c|c|c|c|c|}
\hline 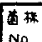 & 患者 & & 診㫝市 & $\frac{\text { 椬 }}{4}$ & 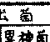 & th & 虑者 & 114 & 診妡名 & 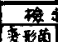 & 5 \\
\hline 7 & 大o & 8 & $+4 \times 49$ & + & + & 27 & Ton & 18 & 级 & + & + \\
\hline 2 & 末0 & 9 & & + & + & 28 & mo & 9 & $112124+2$ & + & + \\
\hline 3 & OD & 8 & 直 作 政 & & & 29 & 10 & If & & $\leftarrow$ & + \\
\hline 4 & 山 & s & & + & + & 30 & 10 & 8 & & + & - \\
\hline 5 & 70 & $f$ & & + & & 31 & 客o & f & , & + & + \\
\hline 6 & 川1 & t & , & + & & 32 & | & $\delta$ & & + & + \\
\hline 7 & $\begin{array}{ll}4 & 0\end{array}$ & $\&$ & 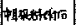 & + & + & 33 & wotko & 8 & & + & - \\
\hline 8 & 传。 & q & - & + & - & 34 & 皮。 & 8 & 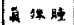 & + & \\
\hline 9 & $=0$ & $s$ & . & + & & 35 & 和。 & if & 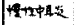 & + & \\
\hline 10 & $\begin{array}{ll}6 & 0\end{array}$ & $\delta$ & . & + & & 36 & oxto & 15 & & & + \\
\hline 11 & 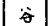 & 9 & 4 & + & - & 37 & tho & 9 & 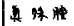 & + & - \\
\hline 12 & 《ar & 古 & , & + & + & 38 & so 0 & 9 & 1948 & + & + \\
\hline 13 & 10 & $a$ & 看 & + & + & 39 & 今。 & 5 & & + & + \\
\hline 14 & |OH & $t$ & 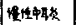 & + & & 40 & $O x(x)$ & t & & + & - \\
\hline 15 & सO & 18 & & + & + & 41 & $\mid 0: x(x)$ & 8 & & + & - \\
\hline 16 & 西 0 & 8 & " & + & & 42 & lon & t & & + & + \\
\hline 17 & 高。 & 7 & , & $\leftarrow$ & + & 43 & 而。 & 5 & t & + & + \\
\hline 18 & 洪 & 8 & ? & + & - & 44 & 10 & $q$ & 4 & + & + \\
\hline 19 & 吉 & 8 & 9 & + & + & 45 & 票。 & 5 & & & + \\
\hline 20 & 00 & 운 & 10 & + & & 46 & $1 \times 10$ & f & & + & - \\
\hline 21 & $10 \mathrm{~F}$ & t) & 谓牲中㔭 & + & + & 47 & lon: & 5 & + & + & + \\
\hline 22 & ○㱚 & f & , & + & & 48 & 10 & 5 & 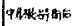 & + & - \\
\hline 23 & $\therefore 0$ & 8 & $\Rightarrow$ & + & & 49 & $3 \approx 0$ & 8 & 192078 & & \\
\hline 24 & 小。 & $\delta$ & 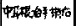 & + & + & 50 & OHor: & 49 & & + & + \\
\hline 25 & 敩 & t & & + & + & 51 & țo & i & & & + \\
\hline 26 & $\oplus 0$ & if & , & + & $T$ & 52 & 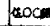 & $\delta$ & , & + & + \\
\hline
\end{tabular}




\section{III．実験方法及ひ実験成結}

A 性状

1) 形態

形態はグラム陰性の長短不同の短桿菌で周囲性鞭 毛を有し芽胞及び萊膜はない，普通培地飞培養の際 は所謂遊走性によつて培地全体に搪つて発育し特異 な臭気を有している。

2) 生物学的泩状

変形菌 52 菌株に䔬便より分離したProvidencia 2 菌株を加光，之等についてゲラチン液化，Christensen 尿素培地によるウレアーゼ試験インドール
及び硫化水素産生の他，各種の精の分解能等を検查 した. 糖の種頑は Adonitol, Dulcitol, Sorbitol, Arabinose, Xylose, Rhamnose, Maltose, Salicin, Inositol, Lactose, Sucrose, Mannitol, Glucose であつて培㦈後 7 日間観察した.

以上の検査の力法はすべて伝研の「細菌学実習据 要」10)によつた。

椧査成績は表 2 亿示す通りで Pr. Vulgaris は全 菌株子すSalicin 歹び Sucroseを1日で分解し， Pr. mirabilis は Sucrose t7 日以内に分解した わのが 23 菌株，分解しないものが 11 菌株，残りの

表 2 生物学的性 状

\begin{tabular}{|c|c|c|c|c|c|c|c|c|}
\hline & 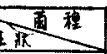 & Prvulgaris & & Pr.mir & abilis & Prmorganii & Pr rettgeri & Providencia \\
\hline & Adonitol & - & $=$ & - & - & - & + & - \\
\hline & Dulcitol & - & - & - & - & - & - & - \\
\hline 糖 & Sorbitol & - & - & - & - & - & - & - \\
\hline & Arabinose & - & - & - & - & - & - & - \\
\hline & Xylose & + & + & + & + & - & - & - \\
\hline$\hat{\imath}$ & Rham nose & - & - & - & - & - & - & - \\
\hline & \begin{tabular}{|} 
maltose \\
Salicin
\end{tabular} & + & - & - & - & - & - & - \\
\hline & Inositol & - & - & - & - & - & + & - \\
\hline 能 & Lactose & - & - & - & - & - & - & - \\
\hline & Sucrose & + & - & \pm & + & - & - & + \\
\hline & Tannitol & - & - & - & - & - & + & - \\
\hline & Glucose & + & + & + & + & + & + & + \\
\hline & $\begin{array}{l}\text { lole } \\
s \text { 萑生生生 }\end{array}$ & $\begin{array}{l}+ \\
+\end{array}$ & $\overline{+}$ & $\overline{-}$ & + & + & + & + \\
\hline & Lation $\hat{n}$ 解 & + & + & + & + & - & - & - \\
\hline & rea 合的 & + & + & + & + & + & + & - \\
\hline & $\begin{array}{l}\text { 公期面䋇 } \\
\text { No. }\end{array}$ & $\begin{array}{l}14.24,32 . \\
44,51\end{array}$ & $\begin{array}{l}2,4.7 .919 \\
22.25 .33 \\
43.50 .52 .\end{array}$ & $\begin{array}{l}11.15 .1623 \\
29.39 .41 .47\end{array}$ & 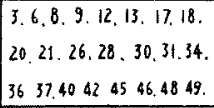 & 27.35 .38$. & 1. 5. & 101.102 \\
\hline & 面株数 & 5 & 11 & 8 & 23 & 3 & 2 & 2 \\
\hline
\end{tabular}

8 菌株は7 日旦内に分解か非分解か 判定出来なから 心.及 Salicin については全菌株とも7 日以内には 分解しなからた。 Pr. morganii は Sucrose 解しなかつた. Pr. rettgeri は Adonitol 及び Salicin, Inositol を分解し Sucrose を分解しなか つた.

以上 Kauffmann ${ }^{11)}$ 及び Bergey ${ }^{12)}$ 飞従つて 52 菌株打 Pr. vulgaris 5 菌株，Pr. mirabilis 42 菌 株, Pr. morganii 3 菌株, Pr. rettgeri 2 菌株类 分類した。

\section{3）熱比対する抵抗性}

Pr. vulgaris No. 14 , No. 24 及び Pr. mirabilis No. 3 , No. 34 , Pr. morganii No. 27 , No. 35 , Pr. rettgeri No. 1, No. 5, Providencia No. 101, No. 102 計 10 菌株见ついて $50^{\circ} \mathrm{C}$ 及び $55^{\circ} \mathrm{C}, 60^{\circ} \mathrm{C}, 70$ ${ }^{\circ} \mathrm{C}$ 飞赫いて各々 5 分，10 分，15 分，30 分にて耐 熱性を調べた。各々 $50^{\circ} \mathrm{C}, 55^{\circ} \mathrm{C}, 60^{\circ} \mathrm{C}, 70^{\circ} \mathrm{C}$ の恒 温慒に滅菌ブイョン $5 \mathrm{cc}$ を入れた中試験管を置き ブイョン温度が規定の温度になるよう5 分以上を経 て，之にブィン $37^{\circ} \mathrm{C} 20$ 分間培盖の菌夜を期込 
ビペットにて1滴笲壁にさわらぬよう滴下混和し規

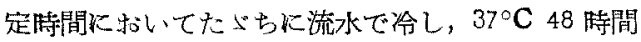
培盖後判定した。

成結は表 3 の通り $50^{\circ} \mathrm{C}$ に打いては 30 分火ても

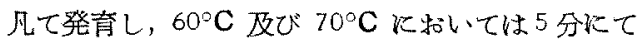

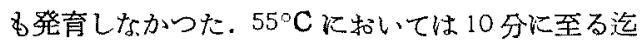
発育するものが多く15 分にて発育するものが 3 菌 株あり，菌株によつて差異方見られた。

表 3 渻に対する抵抗性

\begin{tabular}{|c|c|c|c|c|c|c|c|c|c|c|c|}
\hline \multirow{2}{*}{ 温 } & \multirow{2}{*}{ 成 } & \multicolumn{2}{|c|}{ Pr vulgaris } & \multicolumn{2}{|c|}{ Pr merabelis } & \multicolumn{2}{|c|}{ Pr. morganit } & \multicolumn{2}{|c|}{ Pr. rettgeri } & \multicolumn{2}{|c|}{ Providencia } \\
\hline & & No !4 & No 24 & No 3 & No 34 & No. 27 & $N \alpha 35$ & No 1 & No. 5 & No.101 & No 102 \\
\hline \multirow{4}{*}{$50^{\circ} \mathrm{C}$} & $5^{\prime}$ & + & + & + & + & + & + & + & + & + & + \\
\hline & $10^{\circ}$ & + & + & + & + & + & + & + & + & + & + \\
\hline & $15^{\prime}$ & + & + & + & + & + & + & + & + & + & + \\
\hline & $30^{\circ}$ & + & + & + & + & + & + & + & + & + & + \\
\hline \multirow{4}{*}{$55^{\circ} \mathrm{C}$} & $5^{\circ}$ & + & + & + & + & + & + & + & + & + & + \\
\hline & $10^{\prime}$ & - & + & + & + & + & & + & + & - & - \\
\hline & $15^{\prime}$ & - & + & - & + & - & & + & - & - & - \\
\hline & $30^{\prime}$ & - & - & - & - & - & - & - & - & - & - \\
\hline \multirow{4}{*}{$60^{\circ} \mathrm{C}$} & $s^{\prime}$ & - & - & - & - & & - & - & - & - & - \\
\hline & $10^{\circ}$ & - & - & - & - & - & - & - & - & - & \\
\hline & $15^{\prime}$ & & - & & - & - & - & - & - & - & $\rightarrow$ \\
\hline & 30 & - & - & - & - & & - & - & - & - & - \\
\hline
\end{tabular}

4）石崖酸に娰する抵抗性

日本公毷保険協会雑誌法 13) に上り 前培地後塔地 共河，肉ェキス $5.0 \mathrm{~g}$ ， ペプトン $10 \mathrm{~g}$, 食塩 $5.0 \mathrm{~g}$, 蒸 溜水 $1000 \mathrm{cc}$ の組成からなる $\mathrm{pH} 6.8$ のブィヨン培 地と化学用の純粋な石矢酸を使用し，80倍，90倍， 100 倍, 110 倍，120 倍稀噃無に 2.5 分及び 5 分，10 分，15 分に括いて前記 10 菌株の石炭酸飞対寸る抵 抗性を調べた。常火 $20^{\circ} \mathrm{C}$ の湯槽に扔いてて行い、各稀 釈每飞 $37^{\circ} \mathrm{C} 24$ 時間培養の菌夜 ICC 管壁にさわ

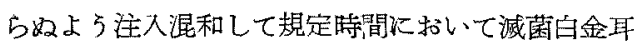
そて 1 白金䌽り媵培地飞移し $37^{\circ} \mathrm{C} 48$ 時間培養 後判定した。

成績は溒 4 の通り Pr. morganii No.27を除き 全菌株と\&80倍稀积では 2.5 分にて死減し, 又5 分 にて発育し10分にて死減するものについてては Pr. vulgaris 2 菌株, Pr. mirabilis 2 菌株, Pr. mor. ganii 1 菌䏭が90倍稀积に括いてであり，Pr. rettgeri 2 菌株は 100 倍稀釈, Providencia は110倍 稀䐆においてであつた。

5) サルフア剂及び抗牛物質に対寸る感受性
表 4 石炭酸に封する抵抗性

\begin{tabular}{|c|c|c|c|c|c|c|c|c|}
\hline Pr. vulgaris & \multicolumn{4}{|c|}{ No. 14} & \multicolumn{4}{|c|}{ No. 24} \\
\hline 稀 㔀 & 2.5 & 5 & 10 & 15 & 2.5 & 5 & 10 & 15 \\
\hline $1: 80$ & - & - & - & - & - & - & - & - \\
\hline $1: 90$ & + & + & - & - & + & + & - & - \\
\hline $1: 100$ & + & + & + & $t$ & + & + & - & - \\
\hline $1: 110$ & + & + & + & + & & + & + & + \\
\hline
\end{tabular}

\begin{tabular}{|c|c|c|c|c|c|c|c|c|}
\hline Pr. milabilis & \multicolumn{4}{|c|}{ No. 3} & \multicolumn{4}{|c|}{ No. 34} \\
\hline 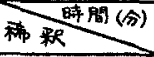 & 2.5 & 5 & 10 & 15 & 2.5 & 5 & 10 & 15 \\
\hline $1: 80$ & - & - & - & - & - & - & - & - \\
\hline $1: 90$ & + & + & - & - & + & + & - & - \\
\hline $1: 100$ & + & + & + & - & + & + & + & - \\
\hline $1: 110$ & + & + & + & + & & + & 7 & + \\
\hline
\end{tabular}

\begin{tabular}{|c|c|c|c|c|c|c|c|c|}
\hline Pr. morganii & \multicolumn{4}{|c|}{ No. 27} & \multicolumn{4}{|c|}{ No. 35} \\
\hline 稀积 & 2.5 & 5 & 10 & 15 & 2.5 & 5 & 10 & 15 \\
\hline $1: 80$ & + & - & - & - & - & - & - & - \\
\hline $1: 90$ & + & + & + & - & + & + & - & - \\
\hline $1: 100$ & + & + & + & + & $t$ & + & + & - \\
\hline $1: 110$. & + & + & + & + & + & + & + & + \\
\hline
\end{tabular}

\begin{tabular}{|c|c|c|c|c|c|c|c|c|}
\hline Pr. rettgeri & \multicolumn{4}{|c|}{ No, 1} & \multicolumn{4}{|c|}{ No. $S$} \\
\hline 稀跌周 & 2.5 & 5 & 10 & 15 & 2.5 & 5 & 10 & 15 \\
\hline $1: 80$ & - & - & - & - & - & - & - & - \\
\hline $1: 90$ & + & - & - & - & + & - & - & - \\
\hline $1: 100$ & + & + & - & - & + & + & - & - \\
\hline $1: 110$ & + & + & + & + & & $t$ & + & + \\
\hline
\end{tabular}

\begin{tabular}{|c|c|c|c|c|c|c|c|c|}
\hline Providencia & \multicolumn{4}{|c|}{ No. 101} & \multicolumn{4}{|c|}{ No. 102} \\
\hline 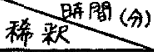 & 2.5 & 5 & 10 & 15 & 2.5 & 5 & 10 & 15 \\
\hline $1: 90$ & - & - & - & - & - & - & - & - \\
\hline $1: 100$ & 一 & - & - & - & + & - & - & - \\
\hline $1: 110$ & + & + & - & - & + & + & - & - \\
\hline $1: 120$ & + & + & + & + & + & + & + & + \\
\hline
\end{tabular}

感受性ディスタを使用し Sulfaisoxazol, Penicilline (PC), Dihydrostreptmycine (SM), Chloramphenicol (CM), Terramycine (TM), Aureomycine (AM) について行い，文特に感受性を 
示した SM 及び CM について稀釉法によつて行 つた. 感受性ブイスクは普通寒天培地とアルフア都 用の Müller, Hinton 培地を使用し，前記 10 菌株 のフィョン $37^{\circ} \mathrm{C} 20$ 時間培養菌液の 駉込ピペット

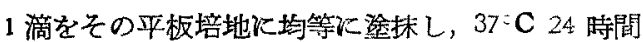
培養後に生じた阻止帯の有無により(十) 或は(一) とした。

試鈳管稀釈法にては SM, CM の $1 \%$ 精加ブイ ン稀釈液学使用し各稀积每们同様ブイシン培養菌夜 1 白金耳を接稙し $37^{\circ} \mathrm{C} 24$ 時間培養後透明さをもつ て発育阻止と判定した。

成績は表 5 の通り感受性を示したのは SM，CM であつた。サルフア剂に対しては Providencia No. 101 菌株を除き凡抵抗性を示した。PC 亿対 しても抵抗性を示するのが多からた。

表 5 サルフア郕及び抗生物筫に対する 感受性（ディスクによる）

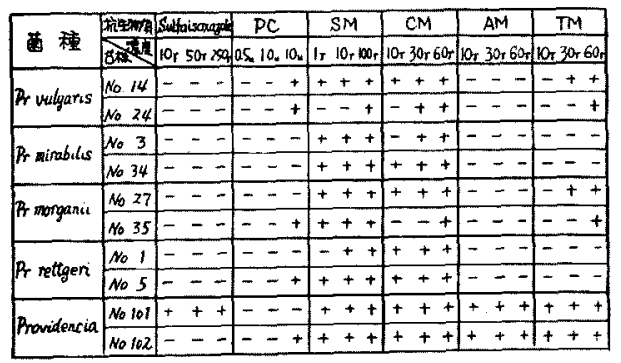

表 $6 \mathrm{SM}$ 及び CM に対する抵抗性

\begin{tabular}{|c|c|c|c|}
\hline \multicolumn{2}{|c|}{ 菌椋NO. } & $S M y_{c c}$ & CM $x$ \\
\hline \multirow{2}{*}{ Pr. vulgaris } & 14 & $10-100$ & $1-10$ \\
\hline & 24 & $500-1000$ & $10-100$ \\
\hline \multirow{2}{*}{ 7.mirabilis } & 3 & $1-10$ & -100 \\
\hline & 34 & $1-10$ & $0-100$ \\
\hline \multirow{2}{*}{ Pr.morganii } & 27 & $1-10$ & \\
\hline & 35 & $1-10$ & $100-125$ \\
\hline \multirow{2}{*}{ Pr.rettgeri } & 1 & $1-10$ & $10-100$ \\
\hline & 5 & $10-100$ & $10-100$ \\
\hline \multirow{2}{*}{ rovidencia } & 101 & $1-10$ & $1-10$ \\
\hline & 102 & $1-10$ & $10-100$ \\
\hline
\end{tabular}

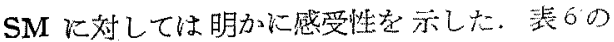

通り稀釉法汇よつて子 3 菌株を除き凡て $10 \mathrm{r} / \mathrm{cc}$ 上 下で抑制した. 他の2 菌株は 10〜100r/ccで，1 菌 株のみ 500〜1000 / / cc で抑制した。

CM 亿対しては大部分感受性を明か儿示し，稀釈 法にて 10 100 / cc で抑制したものが多く 1 菌 株のみ 100〜125r/cc で抑制した。

AM 及ざ TM に対しては大部分が抵抗性を示し Providencia の感受性を示した，又 TM 飞対し $\tau$ Pr. vulgaris 及び Pr. morganii の及が若干感 受性を示した。

6）マロスに対寸万病原性

Pr. vulgaris No. 14, Ni. 24 及び Pr. mirabilis No. 3, No. 34, Pr. morganii No. 27 , No. 35 , Pr. rettgeri No. 1, No. 5 について以下の実験を行つ た。

a)ブイヨン培盖液及び生菌浮遊液のマウス 儿﨎する病原性

普涌ブイョン $37^{\circ} \mathrm{C} 18$ 時間培養液 $0.3 \mathrm{cc}$ と普通 寒天 $37^{\circ} \mathrm{C} 18$ 㭙間培荃の生菌の食塩水浮遊液を 0.3 cc を体重的 $12 \sim 13 \mathrm{~g} の$ マ スの腹膑内に注射し 5 日間観察しだ。

成績は普通プイヨン培竞痽の病原性については全 菌株ともマッスを慗死させた。

生菌浮游液にては表子の通り菌株によつて多少の 差異方見られたがこれは病篗より比較的新しく分離 されたものと古いものとの差晎で方つた。

表 7 生菌浮遊液のマッスに刘する翫原性

\begin{tabular}{|c|c|c|c|c|c|c|c|c|}
\hline \multirow{2}{*}{ 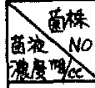 } & \multicolumn{2}{|c|}{ Pr, vulgaris } & \multicolumn{2}{|c|}{ Pr.minabilis } & \multicolumn{2}{|c|}{ Ar morganii } & \multicolumn{2}{|c|}{ Pr. rettger } \\
\hline & 14 & 24 & 3 & 34 & 27 & 35 & 1 & 5 \\
\hline 8 & $5 / 5$ & & $5 / 5$ & & & & $5 / 5$ & \\
\hline 4 & $5 / 5$ & & $5 / 5$ & & $5 / 5$ & $5 / 5$ & $5 / 5$ & $5 / 5$ \\
\hline 2 & $2 / 5$ & $5 / 5$ & $4 / 5$ & $5 / 5$ & $5 / 5$ & $4 / 5$ & $4 / 5$ & $4 / 5$ \\
\hline 1 & $1 / 5$ & $5 / 5$ & $2 / 5$ & $5 / 5$ & $3 / 5$ & $3 / 5$ & $3 / 5$ & $3 / 5$ \\
\hline 0.5 & $\% / 5$ & $5 / 5$ & $3 / 5$ & $5 / 5$ & $3 / 5$ & $1 / 5$ & $3 / 5$ & $2 / 5$ \\
\hline 0.25 & $9 / 5$ & $5 / 5$ & $9 / 5$ & $5 / 5$ & $2 / 5$ & $1 / 5$ & $9 / 5$ & $2 / 5$ \\
\hline 0.125 & & $3 / 5$ & & $3 / 5$ & $\%$ & $\% / 5$ & & $\% / 5$ \\
\hline 0.063 & & $\% / 5$ & & $2 / 5$ & & & & \\
\hline
\end{tabular}

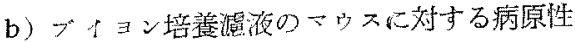

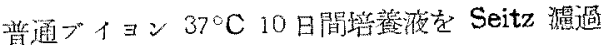


器にて濾過乙無菌試験後, 体重約 12〜13g のマウ スに対して $0.3 \mathrm{cc}$ と 2 倍稀勫液の $0.3 \mathrm{cc}$ の腹腔内注 射を行つた。

成續は表 8 の通り殆んど 毒性は認められなから た.

表 8 ブイヨン濾液のマゥスに対する病原性

\begin{tabular}{|c|c|c|c|}
\hline \multicolumn{2}{|c|}{ 菌楼 No. } & 原液 & 2偉稀积流 \\
\hline \multirow{2}{*}{ Pr.vulgaris } & 14 & $\frac{0}{5}$ & $\%$ \\
\hline & 24 & $2 / 5$ & $2 / 5$ \\
\hline \multirow{2}{*}{ Pr.mirabilis } & 3 & $\frac{1}{5}$ & 15 \\
\hline & 34 & $\frac{9}{5}$ & $\frac{0}{5}$ \\
\hline \multirow{2}{*}{ Pr.morganii } & 27 & $\frac{1}{5}$ & $\frac{9}{5}$ \\
\hline & 35 & $\frac{9}{5}$ & $\frac{9}{5}$ \\
\hline \multirow{2}{*}{ Pr. rettgeri } & 1 & $3 / 5$ & $9 / 5$ \\
\hline & 5 & $3 / 5$ & $\frac{0}{5}$ \\
\hline
\end{tabular}

B モルモットに括ける実験的中耳炎

先に、ゥスについて菌の毒力を定めた変形菌 4 菌 種別に 8 菌株を $37^{\circ} \mathrm{C} 18$ 時間培盖後 $2 \mathrm{mg} / \mathrm{cc}$ 及び $4 \mathrm{mg} / \mathrm{cc}$ の生菌浮遊液を作り，その約 $0.1 \mathrm{cc}$ を鼓膜 正常, ブライェル氏反忘正常にしてX線写真におい。 て中耳腔正常と認められた体重約 $450 \mathrm{~g}$ 内外の成熟 モルモット12例において菌種別に各3例の左中耳 腔に注入し，臨床的並び飞 細菌学的観察を行い14 日後断頭し更に病理組織学的検索を行つた。

\section{1) 臨床的隺察}

菌液注入後 9 例飞括い,て侸日不安状態の下に急性 化膿性中耳炎を起し，搏動性飞獎液性分泌物が外耳 道临出していた．1 例は2 日後に同様の症状を呈 し，又他の 2 例は分泌物を認めず鼓膜の溷濁，肥厚 のみを認めた．分归物排泄の期間は約 7〜8 日比 て3〜4 日後より減少しその後次第に治痖の傾向を 示した.

2) 菌検出

発症後 3 日及び 7 日後は分沙物から断頭後は鼓室 胞から塗抹標本と培盖熖よつて, 菌検出を行い全例 に招いて变形菌を確認した，而して2例においては 白色ブドゥ球菌の混合感染を認めた。
3) X線検查

ニーテレ麻酔を行い伏臥位汇て正常並びに発症後 7 日及西断頭後の頭部を撮影した。

全例飞执いてて発症後7 日後及び 14 日後，共に患

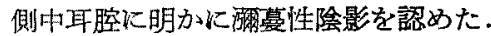

4) 凝集反応

実験前の正常血清及び発症 7 日後に一部採血し， 14 日後断頭前に 全採血し各々影集反応を行つた。 血清は $56^{\circ} \mathrm{C} 30$ 分にて非動化し各稀釈毎に当菌液 1 滴滴下混和し， $37^{\circ} \mathrm{C} 2$ 時間水室に 24 時間放置し た後判定した。

Agglutinoscope そよつて認められ得る弱い陽性 を示し正常血清に执いては陰性なるの8例，残りの 4 例中 2 例が 5 倍弱陽性，1 例が 10 倍弱陽性， 1 例 が 20 倍陽性であり，発症後 7 日後にては 40 倍陽性 のむの 2 例, 80 倍陽性のむの 5 例, 160 倍陽性のむ の 4 例， 640 倍のちの 1 例に.して，発症後 14 日後 にては 10 倍陽性の 601 例, 80 倍陽性の の3 例, 160 倍陽性の $\delta$ の 3 例, 320 倍陽性のもの 4 例, 640 倍陽性のもの 1 例であつた.

5) 病理組織学的検査

断頭後患側及び対照側共にッイットマーク氏液に て 10 日閒固定， $5 \%$ 硝酸にて 3 週間脱灰後，パ フインにて包埋しーマトキシリンェホジン染色炕上 り主として鼓室胞の粘膜並びに骨組織飞ついて病理 織学的検索を行つた。

全例に於いて化呩性炎症症状を示していたが症例 によつてその程度は種々であつた．軽度のるのは上 皮下に扒いて淋巴球又はプラズ、細胞の浸潤を認 め，高度のものは上皮は㔀離され間質結締織烦症 が抎大し広範な壤死を起し白血球の強い浸潤を認め た．大部分は上皮の肥厚及び上皮下の細胞浸潤， 血，浮腫などが認められた．骨壁には新生像が著明 であり，炎症症状の強いるのに括いては吸收像が混 在し此の両者の割合は炎症症状の強いすの程吸収像 が著明に認められた．炎症の内耳に波及したるのは 4 例でその 中の 1 例はヌルチ氏器が膿場の中に浮い ているよ5な所見を呈していた。

\section{主な実験例}

No. 3 , Pr. mirabilis No. $34,2 \mathrm{mg} / \mathrm{cc}$ 菌液注入後，翌日䊢液性分沦物が搏動性に外耳道 
に湓出し8 日後消失した。発症後 3 日，7日，14日 共に同一菌を検出し，X線所見は7日後，14日後

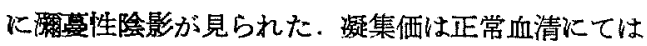
陰性，7 日後 80 倍陽性，14 日後10 倍陽性であつ た。

病理組織学的所見は上皮は大部分剥離しているが 上皮下飞充血，浮盾，細胞浸潤が認められるが腔の 内面が最す甚だしく骨壁に近く次第炕炎症は弱い， ・骨壁には骨新生が見られ，骨吸収は殆んどない，細 胞の成分は白血球が最も多いが形細胞の浸潤も認 められた。

No. 8 , Pr. vettgeri No. $1,4 \mathrm{mg} / \mathrm{cc}$

菌液注入後，14 日に至るまで鼓膜は溷濁肥厚を 示すのみで分泌物は認められず，14 日後に鼓室胞 より同一菌を検出した，X線所見は7日，14日後 共沉濃い陰影があり凝集価は正常血清にては陰性， 7 日後 160 倍陽性, 14 日後 320 倍陽性, 病理組織学 的所見は主《浮腫と上皮下の細胞浸潤であり，細胞 には白血球少なく淋巴球，プラズ、細胞が多かつ た. 骨壁には骨新生が著明であつた。

No. 12 , Pr. mirabilis No. $34,4 \mathrm{mg} / \mathrm{cc}$

菌液注入後, 翌日嶈液性分泌物が外耳道に溢出し 4 日挠膿性となり 7 日後に消失し発症後 3 日及び 14 日後に同一菌を検出したが 7 日後にはその他白色フ トゥ球菌をむ検出した。 X線所見は7日，14日後 共に陰影が見られたが特に7日後に著しく，㠜集価 は正常血清にては陰性，7日，14 日後共飞 80 倍陽 性であつた. 病理細織学的所見は炎症強く鼓室胞内 には澧婸がありコルチ氏器は浮腫を呈していた。骨 壁には骨吸収著しく一部には骨新生も認められた。

\section{VI. 総括及び考按}

慢性化膿性中耳炎成立飞ついてて種々の因子即ち体 質, 局所解剖学的関保等の他起炎的の存在を軽視出 来ないことは勿論である.その桧出菌の大部分を占 めるのが変形菌であることは, Hesse ${ }^{14)}$, Wirth ${ }^{15)}$, Friedmann, 小西 ${ }^{16)}$, 䂺野 ${ }^{17)}$ 等によつて報告され ている. 然し变形菌の存在がその起炎菌として或は 二次感染として意義があるか否かる決定することは 至難である。然し病原性の存在についてては疑 5 べく あない、以下著者の行つた奏験成樍に文献的考繁を

$2-41$
加えてみると，

1）検出率认就いては 202 例中 52 菌株即ち $25.7 \%$ であるが, Hesse は1 159 例中 $24 \%$, Wirth は37\%， Friedmann は27\%，小西性 $24 \%$ ，䂺野は $27 \%$ の 検出菌を報告している. 又52 菌株中 Pr. mirabilis が80\%を占めたことは Levines ${ }^{18)}$ が尿より90\%， 又 Rustigian \& Stuart ${ }^{19}$ ) が㯰尿より $85.7 \%$ の Pr. mirabilis 在检出した成績と略一致する.Perch ${ }^{20)}$ は变形菌の大部分を占めるのが Pr. mirabilis であるのは外界に対する抵抗力強く且つその活潑な 遊走性比よるという。

2）生物学的性状についてては変異を示したものは なかつた. Pr. mirabilis の Sucrose 分解につい て Taylor $\left.{ }^{21}\right)$ 的常以分解し大部分が 3 6 日迄火分 解するとい5 Rustigian \& Stuart は Sucrose 分 解は遅く文大部分が Salicin を分解しないとい〉， 更飞 Pr. morganii の $11 \%$ が Sucrose 解し, Pr. rettgeri の大部分が Mannitol を分解 し，Sucroseを 7〜40日にる解し1/3が Salicinを 分解したと報告している。

3）熱炕対する抵抗性は比較的弱いが菌株により 差晎が見られた，又菌液の湮度による美異があるこ とは当然であるが Meyerhof 22) は酎熱性は弱く54 ${ }^{\circ} \mathrm{C}$ にて 25 35分, $56^{\circ} \mathrm{C}$ にて $5 \sim 10$ 分成育し $60^{\circ} \mathrm{C}$ 飞ては1分にて死滅するとい, Grossmann ${ }^{23)}$ $56^{\circ} \mathrm{C}$ にて 15 分， $60^{\circ} \mathrm{C}$ 亿て 10 分成育するとい,

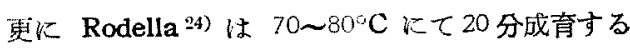
むのがあつたと報告している.

4) 石炭酸行対寸る抵抗性は Pr. vulgaris, Pr. mirabilis, Pr. morganii, Pr. rettgeri, Providencia の菌種別の順に弱いことを示した.

5）サルフア刘及び抗生物質に対する感受性沉つ いては SM と CM が明か炕感受性を示した。サル ファ威の耐性獲得は早いといかれ Lund ${ }^{25)}$ は 68\% は抵抗性を有するとい，5．Pck対しては抵抗性を 有するものが多いと報告さ机ているが逆に Frank 等 ${ }^{26)}$ は大部分感受性があり CM 亿次いで有效で あるとい〉，耐性獲得についても Potee 等 ${ }^{27) は ~}$ Pcには治療の影響は見らないとい〉，Armstrong 等 28) は見られるとい５ＳM には Bliss 等 ${ }^{29)}$ Perch も感受性は大とい５ 文 CM の有効なこと 
6 Bliss 等を始め Perch, Frank 等も認めている。 AM，TM については等テトラ系続には抵抗性を 有するものが多いと，即ち变形菌の大部分を占める Pr. mirabilis のみに抵抗性を有すると Perch 及 び Lutz 等30) は報告し, Perch は Pr. vulgaris 飞対しては TM より AM の方が有效であるとい い，一方 Lutz は著者の成績と同様 Pr. vulgaris 及び Pr. morganii に娰しては AM より TMの 方が有效であると報告している。

6) 病原性については Hauser 以後病原性は感染 又は代謝逤物による組織の分解によるといわれ，或 は叉菌体内毒素によるといわれている．文如何なる 状態の下で Saprophyten である変形菌が病原性を 発揮するかは組織の抵抗力抵下に加えその強大な增 殖力と抵抗性によつて病原菌となることは考觉られ る.、ッスに対してはブイョン培養液及び生菌浮遊 液共に以上の上5に病原性が見られ，最近分離され たものと比較的古く分離されたものとでは病原性に 盖異が見られたが，菌培養の形で出た菌株即ら Pr. vulgaris No. 14 及ðび Pr. mirabilis No. 3, Pr. rettgeri No. 5 等と混合感染を示した他の菌株に於 て病原性に羑異が見られず，又菌種別においても差 異は見られなかつた。Warren \& Lemb ${ }^{31)}$ 《敗血 症患者より分離した菌株で生菌浮遊液及びブイョン

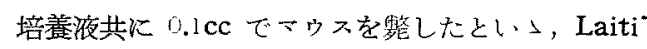

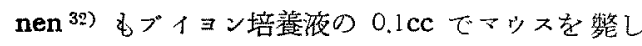
家兔炕 $0.1 \mathrm{cc}$ て病原性があつたと，又 Grossmann はプイヨン培荃液 $0.005 \mathrm{cc} て ゙ 30$ 分間にマウス

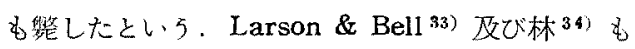
可成りの病原性を報告している。

7)ブイョン培養濾焲の:マウスに対する毒性は殆 んど見られなかつたが，星崎 ${ }^{35)}$ は $37^{\circ} \mathrm{C} 10$ 日プナ ヨン培養後の滤液に更に同一菌を接種し $37^{\circ} \mathrm{C} 10$

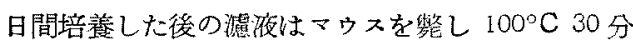
加熱した所謂アンチヴイールスは毒性はなかつたと 報告している. Warren \& Lambは滤液はマけス に対し $0.5 \mathrm{cc}$ 以上で若し培䖯滤液程毒性があると い小 Meyerhof は生菌と源液のマッスに娰する最 少致死量の比率を0.1：2.0 と報告している。

8）笑験的中工炎についてはHesse がモルモツト
4 匹几変形菌による急性化膿性中耳炎を起したとい。 い，又 Wirth は家鬼に慢性中耳炎を起し得たと報 告している，著者は各々 2 菌洙菌種別に計 8 菌哖の 生菌浮遊液 $2 \mathrm{mg} / \mathrm{cc}$ 好゙ $4 \mathrm{mg} / \mathrm{cc}$ を用いモルモッ 、12 例について行い，中10例に於て臨床的に强度 心急性化嶩泩中耳炎を，他の2 例に执いては非穿孔 性中耳炎を起させた。

臨床所見については10例に扣いて 24 時間後殆ん ど不安状態の下に獎液性分必物が搏動性に外耳道に 溫出し大部分が耳翼迄活染していたが，之等の多数 例にては分泌物は3〜4 日後より減少し7日前後に 消失した。中 2 例は明かに二次感染を起し粘稠な膿 性の分必物を諰めた。分必物消失後鼓膜は穿孔が見 られず肥厚及び圂濁を示しているものが多かつた。 非穿孔性中耳炎の2 例に搔いては分速物は耳管に排 泄されたと考克られる。

菌検出については全例に打いて塗抹標本及び培着 にて同一菌が見られ，3日後より14日後に至る迄 菌量の大した消長は見られなかつた。 Wirth は数々 月に亘り变形菌の鼓空胞に甜付る存在を報告してい る.2例に和いて白色ブドウ球菌の存在を見たが 14 日後の鼓空胞には何れる存在しなかつた。

X線所見についてはＨilienbrand ${ }^{36}$ ，が害軻動物 に括ける自発的中耳炎の存在を病理組織学的に証明 しX線所見の必要なことを主張した，著者の契䀫例 にては平常時に鮮明な輪敦をもつた中耳腔が発症後 7日及び14日後にては凡て明白な霉寡性除影を示 し，7 日後と 14 日後と安比較すると明かに 7 日後 により鼬い除影が認められるものがあつた。

凝集反応については Agglutinoscope そよつて認 められ得る弱い陽性を示したが正常血清にお゙いては 㓌性なる。が 8 例, 残り 4 例中 2 例が 5 倍弱陽性, 1 例が 10 倍弱陽性，1 例が 20 倍陽性であり，発症 後は7 日より14日迄凝集洒は10倍より640倍陽任 迄を示し，其の中 80 倍より160倍陽性が大部分で あつた．又7日後交び 14 日後の凝集価を比較する と14日後のものが7日後より低下したるの1例， 上舁を示したもの7例，共に同様であつたもの4 例 であつた。以上の如く実験的中耳炎に絃いては明ら かな凝集反応を示した，先に Hesse は4 匹の実験 


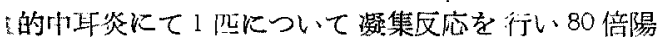
"性を報告している，人間について Wolf $\left.{ }^{3 i}\right)$ は膀胱 炎及び化䃘性霄炎患者に和いて前者は 100 倍，後者 は500倍陽性を示したと述べ，Taylor は㓌性を示 したものが可成りあり凝集反応によつては病原性の 有無について結論し得ないと報告している。

病理組織学的所見についてては Haymann ${ }^{38)}$ は婵 鎖状球菌及び緑膿菌等による奏験的中耳炎において 各起炎菌の種類により病理組織学的所見に相湋があ ることる報告しているが，著者の 垁験成績にては 種たの程度の基る炎症があり，大部分が高度の化脤 性炎症像を示していたが比較的軽いものもあり，最 む強妾のものは間質に炎症があり広範な壊死を起し ていた，骨には新生像及び吸收像が混在し一般に骨 新生が著明であつたが蟲い急泩炎店では吸収像が著 しかつた，又強い炎症では上皮が剝離されたるの多 く，細胞は主として白血球であるが炎店のや」弱い 場合には淋巴球又はプラズ、細胞を主としていた。 㕛4例において内耳に资应が波及していたが，内耳 への移行については Haymann む多数の 奏驗例が あつたことを報告し，Steurer ${ }^{39)}$ あ同様に正円空 攻び卵印窑より移行する事が多いと述ベている，対 照側に軽徽な 細胞浸潤のある矢驗例が見られたが Wirth 同様な事奏を報告している。

\section{V. 結論}

1）慢性化澧性中耳炎患者 202 例の分必物から变 形菌 52 菌株を分離し次の結果を得た。

2）検出率は $25.7 \%$ でその川 Pr. mirabilis が 80 \%去占めた。

3）熹に対与る抵抗性は $60^{\circ} \mathrm{C} 5$ 分で死隇した。

4) 石炭酸に 対する 抵抗性は $90 \sim 120$ 倍 $5 \sim 10$ 分 で死隇する程度であつた。

5) サルフア剂及び 各種抗生物質に対寸る感受性 において SM, CM に対する感受性が最大であつ t.

6) マッスに刘する病原性は中等度であつて純培 養の形で出たものも混合感染の形で検出されたもの

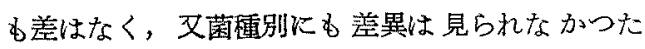
が，新しく分擘されたものは古いるのより病原性が 嫊かつた。

$$
2--43
$$

7）各菌種別に菌液をモルモットの中耳腔に注入 して程度の差こてあれ例外なく急性中耳炎を起し， 其の際X 線写真にて子明らかに陰影を認め，又㠜 集価の陽性化乃洷上景を認め, 更に病理組織学的検 查により鼓音胞の粘膜，骨並びに内耳等に急性炎症

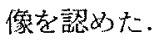

\section{交解}

1) Hauser: Über Fäulnisbakterien und deren Beziehung zur Septikämie, 1885. 2) Kanthack: Z. Ohrenhk, $21: 44,1891$.

3) Lang, J.: Z. Ohrenhk., $67: 247,1912$. 4) Leutert: Arch. Ohrenhk., 46:190, $47: 1,1899$. 5) Lauffs, J.: Arch. Ohrenhk., 70:90, 1907. 6)

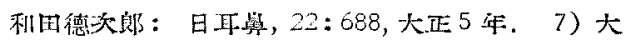
西克保：耳㮢，13：903，昭利15 年，8）Kylin， O.: Acta. oto-laryng., $42: 387,1952$. 9) Friedmann: J. Laryng. 66: 175, 1952. 10) 細 菌学実漗提装，昭和 30 年. 11) Kauffmann: Enterobacteriaceae. 1954. 12) Berger: Manual of determinative bacteriology. 1939. 13)

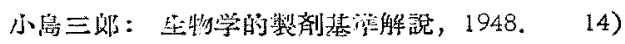
Hesse, W.: Z. Hals-usw. Hk., 29: 360, 1931. 15) Wirth, E: Z. Hals-usw. Hk., $37: 316,1935$.

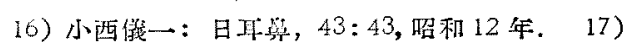

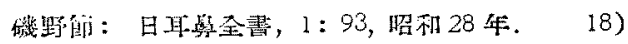
Levines, M.: J. Bacter., 43: 33, 1942. 19) Rustigian \& Stuart: J. Bacter., 49:419, 1945. 20) Perch, B.: Acta. path. et microbiol. scand., $35: 278,1954$. 21) Taylor, J.F.: J. Path. a. Bacter., 31 . 897, 1928. 22) Meyerhof, M.: Zbl. Bakter usw., 24: 18, 55 \& 148, 1898, 23) Grossmann, J.: Beitr. klin. Chir., 30:182, 1901. 24) Rodella, A.: Zbl. Bakter. usw., $27: 583$, 1900. 25) Lund, E. Acta path. et microbiol. scand., 31. 281, 1952. 26) Frank, Wilcox \& Finland: J. Labor, a. clin. Med., 35: 205, 1950. 27) Potee, Wright \& Finland: J. Labor. a. clin. Med., 44:463, 1954. 28) Armstrong \& Larner: J. Labor. a. clin. Med., $37: 584,1951$. 29) Bliss \& Todd: J. Bacter., 58: 61, 1949. 
30) Lutz \& Hofferer: Rev. immun. Paris., 19:69, 1955. 31) Warren \& Lamb: J. med. Res., $44: 375,1924 . \quad$ 32) Laitinen, T.: Zbl. Path., 9:292, 1898, 33) Larson \& Bell: J. exper. Med., 21: 629, 1915. 34) 林阿安：実

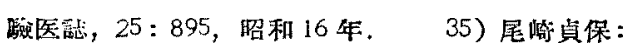
日微生物护理誌，29：1337，昭利 10 年. 36) Hillenbrand, K.. Arch. Ohr-usw. Hk., 138 : 256, 1934. 37) Wolf, S.: Zbl. Bakter, usw., $25: 311,1899$. 38) Haymann, L.. Arch. Ohrenhk., 90: 267, 1913.: 92: 161, 1913.; 93:1, 1914.; 95: 99; 1914. 39) Steurer: Arch.
Ohr-usw. Hk., 112: 160, 1925.

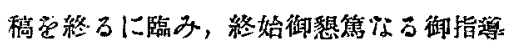

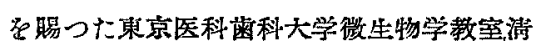
水交这教授に深甚の謝意を蒜し，病理標本 に御指酎を賜つた同病理学教室太田邦天教

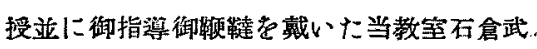
婎教授，松本歭太請所に深謝します。

（原稿到萻=昭利 31,9.21日） 


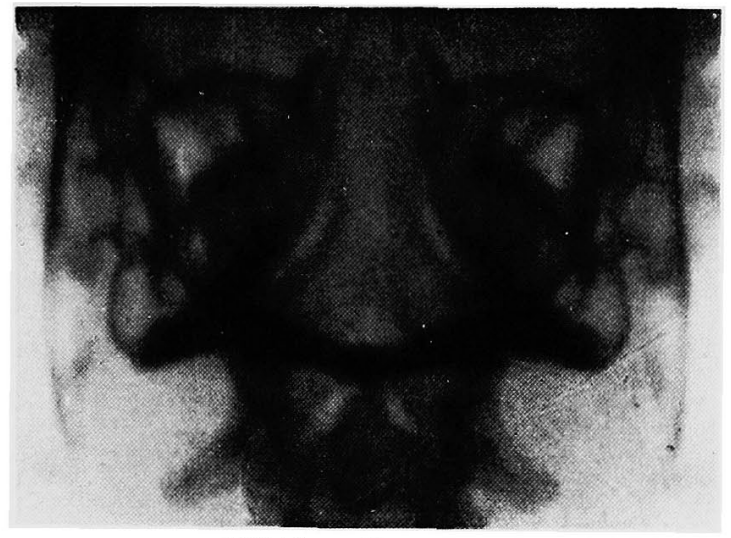

第1图正常待游掼中.耳

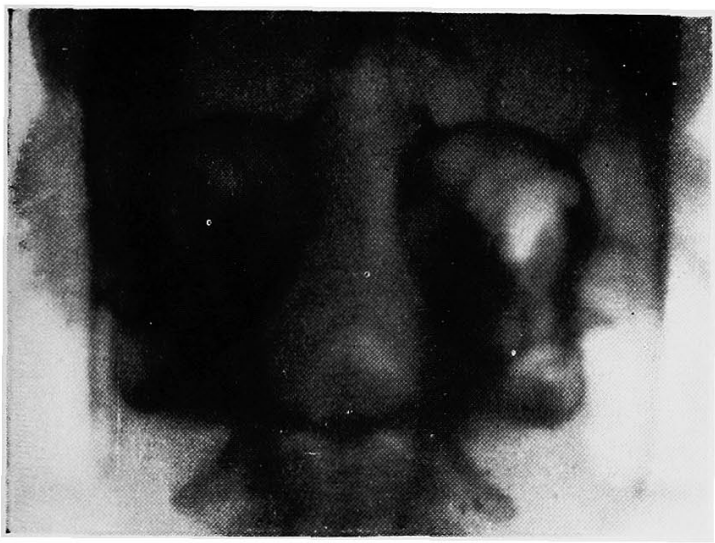

第2図発头後7日 t：患側

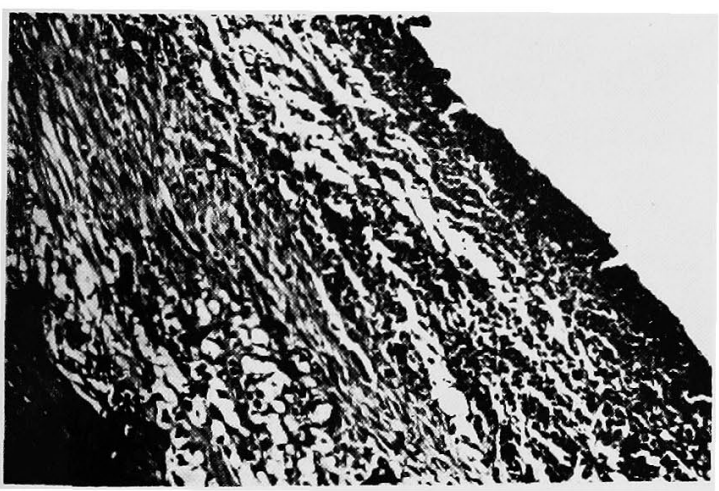

第 4 図炎症它起した鼓室胞粘膜

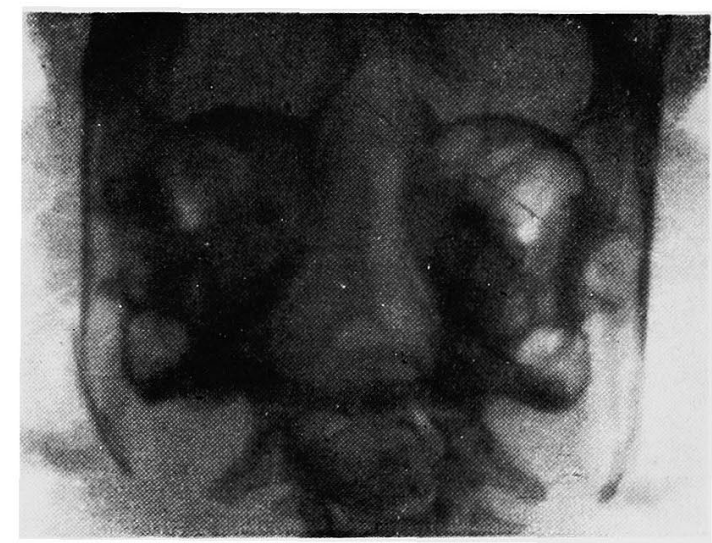

第 3 図発症啳 14日 左：吕側

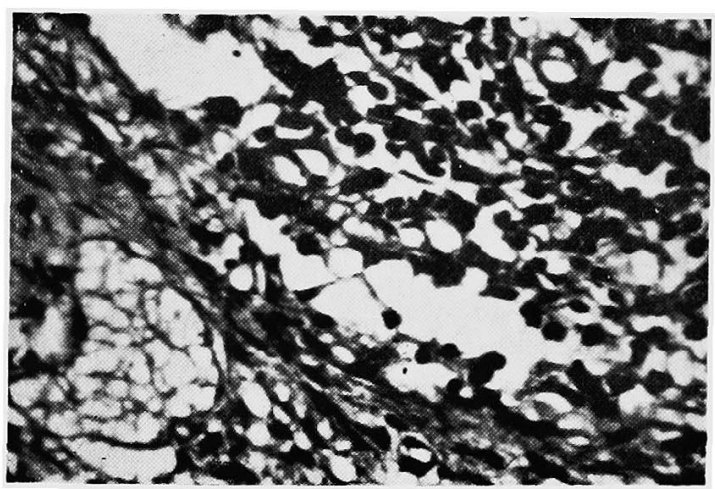

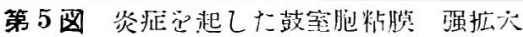

